\title{
Mix Rationality in Weavers Economic Activities in Wajo Regency - South Sulawesi Province
}

\author{
$1^{\text {st }}$ Muhammad Syukur \\ Departemen of Sociology \\ Faculty of Social Science \\ Universitas Negeri Makassar \\ Makassar, Indonesia \\ m.syukur@unm.ac.id
}

\author{
$2^{\text {nd }}$ Andi Ima Kesuma \\ Departemen of antropology education \\ Faculty of Social Science \\ Universitas Negeri Makassar \\ Makassar, Indonesia \\ andi.ima.kesuma@unm.ac.id
}

\begin{abstract}
This study aims to assess and analyze about: 1) How the form of weaver's economic actions in response to market forces entering rural areas; 2) How is the typology of local economic system developed by weavers in Wajo Regency South Sulawesi Province. This research uses constructivist paradigm with qualitative approach. Data collection is done by using in-depth interview, observation, Focus Group Discussion (FGD) and documentation methods. Data analysis is done through data reduction process, data presentation, and conclusion. The examination of data validity is done through four ways, namely: degree of credibility, transferability dependability, and confirmability. The results show that the weaver's economic actions in responding to market forces entering rural areas are characterized by a "mix of rationality" in the conduct of socio-economic life. Gedogan weavers have a rationality that puts forward social solidarity or collectivity inherent in the values and norms that exist in the Bugis society rather than the profit. The economic action of the gedogan weavers is driven more by a sense of high solidarity instead economic gain alone. Whereas the rationality of ATBM weavers tends to be in the midst of the social solidarity or collectivity and individualism or self-interest poles. While weaving entrepreneurs have economic actions that tend to be individualistic rather than collectivity where various actions are always oriented to economic benefits and leads to interdependence with other economic actors. While the typology of local economic system developed by gedogan weavers, ATBM weavers, and weaving entrepreneurs differs from business, moral base, labor position, production and distribution activities and the role of the state.
\end{abstract}

\section{Keywords-Mix Rationality, Economic Action, Weavers}

\section{INTRODUCTION}

Penetration of Capitalism in many developing countries, including Indonesia, causes some of Capitalism values to be adapted and practiced in social-economic life. This condition led into the existence of multiple production mode in developing countries [1]-[2]-[3]. Penetration of global capitalism through trade and colonization into society's social-economic system triggers the change of the socialeconomic order. This condition triggers differentiation, stratification, polarization, and poverty in rural society [1], [4]-[5].

Penetration of capitalism in the social-economic system of Indonesian society occurs in all life aspects, including in weaving sector. Palmer dan Castles [6] stated that, since 1929 to early 1930s, when the world economic depression hit farming/plantation sector in Dutch Indie, it caused workers in both sectors suffered more distress, and increased unemployment rate. Dealing with the situation, the Colonial Government encouraged the development of local small-scale weaving industry. This was expected to change the economic climate to be more conducive for the development of local weaving industry. According to [7][8], 1930 is the first stage of weaving industry blast as well as the weaving technology revolution from gedogan (hand weaving device) to Non-Machine Weaving Tool (Alat Tenun Bukan Mesin-ATBM).

The emergence of weaving entrepreneurs as well as ATBM weavers (commercial and semi-commercial weavers) in Wajo Regency did not instantly put the gedogan weavers (pre-capitalism weavers). Their numbers are still larger than the ATBM weavers in Wajo Regency. Statistical data of Wajo Regency shows that there are 4,982 gedogan weavers with total production of 99,640 pieces of sarong per year, while there are 227 ATBM weavers with total production of 1,589,000 meters of fabric per year. [9].

Weaving production system, over time, changes from traditional and autonomous to the system that is involved in market economy system network. Cultural change in several weavers is marked by the shift of production orientation. Production, which is previously household and custom oriented, becoming market oriented in order to meet the market demand to seek for profit and capital accumulation. However, on the other side, there are weaver with traditional and semi-modern production technique, using family workers, with products made by order from customers and retailers. These different economic actions practiced by those weavers show the variation of economic action practiced by weavers in particular period of time.

Based on that problem, this research is aimed to understand and analyze on "how is the shape of weavers' economic action in facing market power entering the rural area in Wajo Regency, South Sulawesi.

\section{RESEARCH METHODS}

Primary data of the research gained directly from several respondents. Primary data collection technique used were in-depth interview, limited participative observation, documentation, as well as Focused Group Discussion (FGD). Main interview technique used was in-depth interview. Researcher also used informal conversational 
interview, which is a free and spontaneous interview technique [10]. Meanwhile, the secondary data gained from related institutions such as government and custom institutions, as well as written data from various sources such as books, journal, and researches.

Data analysis done in three stages; first, data reduction process focused on selection, simplification, abstraction, and transformation of rough data from field records. In this process, data were sorted into those that relevant to the research focus, and those that do not meet the exclusioninclusion criteria. The second stage was data serving, which involved compiling information into statements that will enable conclusion drawing. Data served in narrative text form, which initially spread and separated on various information sources, then classified according to theme and analysis needs. The third stage was conclusion drawing based on data reduction and serving. Conclusion drawing executed in stages from general conclusion at the data reduction stage, and then become more specific at data serving stage, and become even more specific at the actual conclusion drawing stage. These process chains showed that qualitative data analysis in the research was interactive in nature, start from data reduction, data serving, and conclusion drawing stage over and over again in cyclical way [10]. Examination on data validity refers to [11] view that includes four ways, i.e: credibility, transferability, dependability, and confirmability.

\section{RESULTS AND DISCUSSION}

Businessmen in local economic system of Wajo people are family business-based private sector. The symptom is similar to those in Japan where businessmen rely on family company. Gedogan weavers base their business on nuclear family by placing their wife and daughters as the workers. The production relationship structure is egalitarian. In this structure, weaving activities are conducted based on free time and not restricted to certain working hours. The loom ownership is in the hand of nuclear family and no working division system exists. There is no wage in production activities and production result or woven fabrics sale is used to fulfill family's basic needs. Therefore, all family members could enjoy the result. Weaving activities conducted by gedogan weaver are directed more to fulfilling the basic needs. The less income among husbands to fulfill the family's need is the main cause of wife and daughters to become weaver.

Weaving activities of ATBM weavers are in the hand of the family. Meanwhile, weaving workers consist of their own family members (wife and daughter) and those from the extended family. There are ATBM weavers in Wajo who recruit worker from outside the family but it is conducted based on the recommendation from the family. Male family members often involve in ATBM maintenance, yarn purchasing, and woven fabrics marketing. Relationship structure of business activities in ATBM weaver is hierarchical by placing the wife as the owner of ATBM and as a party who control and perform production activities. Children and weaving workers position, on the other hand, is under the control of ATBM owner in production activity. There is no contractual bond between workers and employer in production activity. The relationship between ATBM owner and workers involves a patron client relationship based on kinship.

Meanwhile, weaving businessmen conduct their activity by depending more on weaving workers from various villages in Wajo Regency. The relationship between the businessmen and weaving workers is non-contractual thus competition to recruit workers is often occurred among the businessmen. Weaving workers is recruited not only based on the closeness of relationship but also on the skills needed, especially workers recruited from working market. The relationship is a patron client relationship. Weaving workers are given freedom to work all time (according to their opportunities and desire) in weaving business owned by the patron.

The position of weaver in Wajo, currently, is as an economic actor played role in providing family- and community-based social guarantee. Therefore, communities around the weaver are part of the success of weaving business actors. Thus local economic system (Sistem Ekonomi Lokal/SEL) of Bugis-Wajo weaver communities is unique based on the perspective of modern capitalist economy, democracy-socialist economy, or communistsocialism.

The above realities indicate that economic system conducted by the three weaver groups are purely family and community initiative without government intervention in regulating the relationship between the existing economic actors. The symptom is similar to those occurred in economic model prevailed in the United States of America where private actors play role in following the existing market mechanism. The difference is that economic actors in Wajo maintain a mutually beneficial partnership with other economic actors. Regulation of local economic relationship occurred in weaving community at Wajo is sourced at norms and values applicable in local community, such as sibali perri/sibali reso, sipakatau/sipakalebbi and lетри ethics. This is what distinguish it from the economic systems prevailed in various countries in the world [12].

Moral base used by gedogan weaver in their economic actions is gotong royong or tolong menolong (mutual assistance) (sibali perri dan sibali reso) and siri and pesse solidarity. ATBM weavers always base their economic action on moral base of gotong royong or tolong menolong (sibali perri and sibali reso [13]. However, in certain limit, they already familiar with wage and there are patronage relationship with other economic actors. Weaver businessmen, on the other hand, basing their action in gotong royong or tolong menolong (sibali perri and sibali reso) but some solidarity are measured with material, competition, and siri and pesse attached to local specific patronage relationship. Competition among weaving businessmen often occurs in terms of worker recruitment, production activity, and distribution. However, they cannot be categorized as pure capitalist economic system like the U.S. economic model since they still perform family management for business activities and the relationship between actors are not exploitative but it is based on kinship ties. In addition, local solidarity is based on patron client relationship where the businessmen provide income source 
for the communities that become their client. In certain condition, however, solidarity is measured by material.

Worker position in local economic system of Wajo people is unknown in gedongan weaver activity. Business activity is conducted by the wife and daughters. Whereas, in economic system conducted by ATBM, workers are sourced from family members (wife and daughters) as well as extended family, and it already familiar with wage. In addition, weaving businessmen purely use waged weaving workers to conduct their business activities. Workers are recruited from rural communities and they come from various regions in Wajo Regency. The relationship between weaving businessmen and weaving workers is based on patronage relationship and it is not exploitative since the businessmen give income and security guarantee to the workers. Workers have freedom to choose to work in their desired employer. However, workers' loyalty to the employer is high since the employer treats the workers humanely by helping their family whenever they are in need. Worker position is unorganized in worker association organization as in four state economic system models in various countries. The condition puts the workers in weak position in economic decision making. It is different to workers in Scandinavian countries who have a relatively strong position thus they have bargaining position with the company. The weak position of weaving workers is compensated by micro process where the company gives working guarantee based on the workers' desire and opportunity. In Japanese economic system, on the other hand, the company gives a life time working guarantee. The weak position of weaving workers is also compensated by assistance in food, goods, and loan if they need them.

In gedogan weaver, production and distribution activities are conducted in local market without government intervention as well as in ATBM weaver. Whereas, in weaving businessmen, the activities are conducted by utilizing local, national, and global markets without government intervention. Production and distribution systems in local level tends to be controlled by weaving businessmen and collecting traders; therefore, wealth distribution among the economic actors involved in weaving activity tends to be imbalanced between weaving businessmen and other weaving actors (gedogan weaver, ATBM weaver, weaving workers, mulberry and silk worm farmers). Economic actors are free to build cooperation with other economic actors in production and distribution activities including market share searching. The symptom is similar to the one that occurs in Scandinavian countries and the United States of America where actors are free to follow market mechanism and the country plays role as a guard to prevent monopoly and cartel.

Market economic system penetration into social economic system of weaver society in Wajo Regency, South Sulawesi, resulted in different response among society. This condition led into the emergence of three weaver groups. Those were: gedogan, ATBM, and entrepreneur weaver. Those groups were having different rationality action in weaving activity. Those actions are as shown in Table 1.
TABLE 1. COMPARISON BETWEEN SUBSTANTIVE AND FORMAL RATIONALITY ACTIONS AMONG THE THREE TYPES OF WEAVER

\begin{tabular}{|c|c|c|}
\hline $\begin{array}{l}\text { Action Type } \\
\text { of Weaver }\end{array}$ & Substantive Rationality & Formal Rationality \\
\hline $\begin{array}{l}\text { Gedogan } \\
\text { Weaver }\end{array}$ & $\begin{array}{l}\text { - Exchange in Weaving activity } \\
\text { (menganai and draw-in) is } \\
\text { reciprocal (mutual assistance) } \\
\text { - Exchange in various life cyclical } \\
\text { activities done by neighbors, } \\
\text { relatives, and friends, also } \\
\text { reciprocal } \\
\text { - Production is oriented to meet } \\
\text { household's primary needs } \\
\text { - Honesty as the main factor in } \\
\text { gaining trust } \\
\text { Risk averse and non-speculative }\end{array}$ & $\begin{array}{l}\text { - Life demands mutual } \\
\text { dependency among } \\
\text { neighbors, relatives, and } \\
\text { friends in meeting daily } \\
\text { needs. } \\
\text { - Weaving is an activity } \\
\text { done by women to } \\
\text { productively killing time } \\
\text { by gaining economic } \\
\text { profit. } \\
\text { Capital formation is done } \\
\text { by children education. }\end{array}$ \\
\hline $\begin{array}{l}\text { ATBM } \\
\text { weaver }\end{array}$ & $\begin{array}{l}\text { - Exchange in various life cyclical } \\
\text { activities done by neighbors, } \\
\text { relatives, and friends, and is } \\
\text { reciprocal (mutual assistance) } \\
\text { - Honesty as the main factor in } \\
\text { gaining trust } \\
\text { - Non-speculative } \\
\text { - Neither creative nor innovative } \\
\text { - Employer-employee relationship } \\
\text { is patronage. }\end{array}$ & $\begin{array}{l}\text { - Exchange in weaving } \\
\text { activity involves money } \\
\text { and service } \\
\text { - Weaving is a primary } \\
\text { activity in gaining } \\
\text { economic } \\
\text { However, it is not yet } \\
\text { becoming the main } \\
\text { income source in } \\
\text { household economic. } \\
\text { - Risk taking (e.g.: selling } \\
\text { gold and borrowing } \\
\text { money to grow the } \\
\text { business) } \\
\text { Capital formation is done } \\
\text { through education, } \\
\text { purchasing gold, as well } \\
\text { as land renting/selling. }\end{array}$ \\
\hline $\begin{array}{l}\text { Weaving } \\
\text { Entrepreneurs }\end{array}$ & $\begin{array}{l}\text { - When they are too busy running } \\
\text { their business, exchange realized } \\
\text { by deputing it to their family } \\
\text { member (wife and children). } \\
\text { - Honesty as the main factor in } \\
\text { gaining trust } \\
\text { Capital forming is done through } \\
\text { charity for social and religious } \\
\text { activities. } \\
\text { Employer-employee relationship } \\
\text { is patronage. }\end{array}$ & $\begin{array}{l}\text { - Exchange in menganai and } \\
\text { draw-in activities involves } \\
\text { money and service } \\
\text { - Entrepreneurs tend to run } \\
\text { their business in their busy } \\
\text { time instead of attending } \\
\text { life-cyclical activities held } \\
\text { by their neighbors, } \\
\text { relatives, or friends. } \\
\text { - Weaving activity is the } \\
\text { main occupation in } \\
\text { gaining profit, as well as } \\
\text { the main source for family } \\
\text { income. } \\
\text { - Risk taking } \\
\text { - Speculative } \\
\text { Creative and innovative } \\
\text { - Capital formation is done } \\
\text { through children } \\
\text { education, purchasing } \\
\text { gold, land renting/selling, } \\
\text { business expansion, } \\
\text { production intensity, and } \\
\text { shop/boutique purchasing. }\end{array}$ \\
\hline
\end{tabular}

The research result shows a difference with the thesis of Polanyi [15] who suggested that economic action in traditional societies embedded onto social, politic, as well as religious institutions of relevant society. Whereas in modern society, market is regulated by a new logic, stated that market regulates itself (self-regulating market) and radically break away from other social institutions. In addition, its economic actions are guided by maximum economic gain. The findings of the research show that economic action of gedogan weaver embedded onto social institution of Bugis Society. However, on the other hand, there are entrepreneurs whose most of their actions are following market mechanism and always working to expand their business, yet there are willing to give charity to others in social and religious activities. Capital formation among the weaver entrepreneurs was not aimed to give a greater contribution 
for these worldly purposes, but also for the sake of the hereafter.

The research expands Weber's rationality theory further. The findings show that instrumental and traditional actions are able to coexist in one particular action. The work of both rationalities in one action shows that rationality possessed by the weavers was "mix rationality". A gedogan weaver was only willing to sell a particular pattern of woven fabric in a particular price for the Bugis Nobles for they receive words form their ancestors. This shows that their activity involves the dimension of traditional action since they are willing to obey the message from their ancestors that sanctify Noble-patterned fabric only for the Noble. Yet, on the other side, they also possess an instrumental rationality since they also gain an economic profit from the fabric they sold to the Noble. Capital formation among the weaver entrepreneurs was not aimed to give a greater contribution for these worldly purposes (instrumental rationality), but also aimed to help society in social-religious activities. Weaving entrepreneurs work hard so that they can eventually able to do the Hajj pilgrimage. This condition shows that value-oriented rationality also worked in their economic actions.

Results of the research also show difference to [15], stated that the action of economic actor always work between under-socialized (rational economic actions and oriented to individual achievement/self-interest) and oversocialized (economic actions guided by rules of values and norms) poles applicable in the society. Granovetter's theory views as if values and norms of customs and religion are sealed from re-translations by actors. The research shows that religious values and norms were open to be translated by weaver community according to their life orientation as well as the social economic condition they faced. The result of the research supports Weber's theory of rationality further [17]-[18]. The findings of the research show the existence of "mixed economic action" where instrumental and traditional rationalities were able to coexist in one particular action done by the weaver.

The research result also shows difference to Granovetter's theory of embeddedness [19], stated that the action of economic actor always work between undersocialized (rational economic actions and oriented to individual achievement/self-interest) and over-socialized (economic actions guided by rules of values and norms) poles. The theory seems to assume that values and norms of culture and religion are static. Whereas, the findings of the research show different meaning of values, norms, and religion among the three types of weaver. This condition shows that values and norms, as well as religious dogma are open to be re-translated according to the action orientation of respective economic actors.

\section{CONCLUSION}

The existence of three types of weaver in Wajo resulted in different economic action. The gedogan weavers possessed economic actions that tended to be more oriented to moral instead of formal rationality, so that their actions always gave priority to solidarity. ATBM weavers possessed economic actions between moral and formal rationalities. Hence, some parts of solidarity in weaving activity had been left behind, while parts of their actions had already oriented towards economic interests. Meanwhile, weaving entrepreneurs tended to feature formal rationality actions than the moral ones. However, their prominent economic roles were not only oriented to give greater contributions in worldly matters, but also give space to the moral economic dimension through charities for social-religious activities. The work of economic action among the three level of weavers in the dimension of formal and substantive rationalities made their actions become "mixed rationalities".

\section{ACKNOWLEDGMENT}

The researcher gives high appreciation to the Government of Wajo Residence for giving permission to the research to be held in their authority. Special appreciation also given to all informants who are faithfully sharing valuable information to us so that all data needed in the research can be collected.

\section{REFERENCES}

[1] K. Jayawardena, Feminism and nationalism in the Third World. Verso Books, 2016.

[2] M. Warschauer, Technology and social inclusion: Rethinking the digital divide. MIT press, 2004.

[3] A. Escobar, Encountering development: The making and unmaking of the Third World. Princeton University Press, 2011.

[4] A. J. Scott, "Social Differentiation and Forms of Life," in The Constitution of the City, Springer, 2017, page. 155-186.

[5] O. Vendina, "Social polarization and ethnic segregation in Moscow," Eurasian Geogr. Econ., vol. 43, no. 3, page. 216-243, 2002.

[6] D. Sibley, Geographies of exclusion: Society and difference in the West. Routledge, 2002.

[7] C. U. Rodrigues, "Changes to urban society in Angola: from limited to multi-criteria stratification," Afr. Stud. Rev., vol. 60, no. 2, page. 161-181, 2017.

[8] J. P. Milesi, E. Marcoux, T. Sitorus, M. Simandjuntak, J. Leroy, dan L. Bailly, "Pongkor (west Java, Indonesia): a pliocene supergeneenriched epithermal Au-Ag-(Mn) deposit," Miner. Depos., vol. 34, no. 2, page. 131-149, 1999 .

[9] Central Bureau of Statistics, District of Wajo in Figures 2016. Wajo, 2016.

[10] M. B. Miles, A. M. Huberman, dan J. Saldana, Qualitative Data Analysis: A Methods Sourcebook, 3 ed. United States of America: Sage Publications, 2014.

[11] E. G. Guba and Y. S. Lincoln, Handbook of Qualitative Research. (Second Edition), Thousand Oaks: Sage Pul. Inc 2000.

[12] Syukur, Muhammad, Social Network of Bugis Weavers at Wajo Regency, South Sulawesi. KOMUNITAS: International Journal of Indonesia Society and Culture. Vol. 8 No,1. page. 155-168, 2016.

[14] Syukur, Muhammad, Arya H. Dharmawan, Satyawan Sunito, Didin S. Damanhuri "Local Wisdom in Social Economic System at Weavers Community Bugis-Wajo". MUDRA. Vol. 28 No,2. page. 129-142, 2013.

[15] F. Block, "Karl Polanyi and the writing of the Great Transformation," Theory Soc., vol. 32, no. 3, page. 275-306, 2003.

[16] M. Granovetter, "Economic institutions as social constructions: a framework for analysis," Acta Sociol., vol. 35, no. 1, page. 3-11, 1992.

[17] B. S. Turner, Weber and Islam, vol. 7. Psychology Press, 1998.

[18] G. Ritzer and Douglas J. Goodman, Modern Sociological Theory. McGraw-Hill, 2004.

[19] M. Granovetter, "Economic action and social structure: The problem of embeddedness," Am. J. Sociol., vol. 91, no. 3, hal. 481-510, 1985. 